\title{
Cultural identity in the consumption of the National Football League by Brazilian fans
}

\author{
BRUNO MELO MOURA ${ }^{1}$ \\ ANdRÉ LUIZ MARANHÃo de SOUZA-LEÃo ${ }^{1}$ \\ ${ }^{1}$ Universidade Federal de Pernambuco (UfPe) / Programa de Pós-Graduação em Administração, Recife - PE, Brazil
}

\begin{abstract}
Brazilians watching the US National Football League (NFL) interact on social media during the broadcast of league games. Since fan consumption practices can establish identities from the intensity of involvement with media products, this research aims to analyze how Brazilian NFL fans constitute cultural identities in their interactions on social media during the broadcast of league games. We use netnography, a method commonly used in studies that seek to understand cultural phenomena that occur through online interactions. The research corpus was formed by messages posted by fans on Twitter hashtags created by the ESPN channels of Brazil, during the games broadcasted in the 20162017 and 2017-2018 seasons. The results indicate three identity categories: nationalism, as a way of projecting an idealized image of a nation; localism, as a demarcation of tensions of the differences existing in the country; and social minorities related to gender and sexual orientation, revealing tensions and conformities in the social construction of these positions. By revealing identities strongly related to the notion of place and different representations of the hetero-masculine, these findings are evidenced as a particular version of the central values of the sport itself in its country of origin.
\end{abstract}

Keywords: NFL. Cultural identity. Fans. Prosumption. Netnography.

\section{Identidade cultural no consumo de fãs brasileiros da National Football League}

\section{Resumo}

Os telespectadores brasileiros da NFL interagem nas mídias sociais durante a transmissão dos jogos da liga. Uma vez que as práticas de consumo de fãs podem estabelecer identidades pela intensidade do envolvimento com os produtos de mídia, a presente pesquisa visa analisar como os fãs brasileiros da NFL constituem identidades culturais em suas interações em mídia social durante a transmissão dos jogos da liga. Para tanto, utilizamos a netnografia, método que é comumente utilizado em estudos que buscam compreender fenômenos culturais que ocorrem por meio de interações online. O corpus da pesquisa foi formado por mensagens postadas por fãs nas hashtags do Twitter criadas pelos canais ESPN do Brasil, durante os jogos veiculados no decorrer das temporadas 2016-2017 e 2017-2018. Os resultados indicam a constituição de três categorias identitárias: nacionalismo, como forma de projetar uma imagem idealizada de nação; localismo, como demarcação das tensões das diferenças existentes no país; e minorias sociais relacionadas a gênero e orientação sexual, revelando tensões e conformidades na construção social dessas posições. Ao revelar identidades fortemente relacionadas à noção de lugar e a representações diferentes da hétero-masculina, tais achados são evidenciados como uma versão particular dos valores centrais do próprio esporte em seu país de origem.

Palavras-chave: NFL. Identidade cultural. Fãs. Prossumo. Netnografia.

\section{Identidad cultural en el consumo de fanes brasileños de la National Football League}

\section{Resumen}

Los espectadores brasileños de la NFL interactúan en las redes sociales durante la transmisión de los juegos de la liga. Dado que las prácticas de consumo de fanes pueden establecer identidades por la intensidad de la participación en los productos de los medios, la investigación actual se propone analizar cómo los fanes brasileños de la NFL constituyen identidades culturales en sus interacciones en las redes sociales durante la transmisión de los juegos de la liga. Para tal fin, utilizamos la netnografía, un método que se usa comúnmente en estudios que buscan comprender los fenómenos culturales que ocurren a través de las interacciones en línea. El corpus de investigación se compuso por mensajes publicados por los fanes en etiquetas de Twitter creadas por los canales de ESPN de Brasil, durante los juegos transmitidos durante las temporadas 2016-2017 y 2017-2018. Los resultados indican la constitución de tres categorías de identidad: el nacionalismo, como una forma de proyectar una imagen idealizada de una nación; el localismo, como demarcación de las tensiones de las diferencias existentes en el país; y las minorías sociales relacionadas con el género y la orientación sexual, revelando tensiones y conformidades en la construcción social de estas posiciones. Al revelar identidades fuertemente relacionadas con la noción de lugar y con representaciones diferentes de la heteromasculina, tales hallazgos se evidencian como una versión particular de los valores centrales del deporte en su país de origen.

Palabras clave: NFL. Identidad cultural. Fanes. Prosumo. Netnografía. 


\section{INTRODUCTION}

Modern society can be understood by its cultural manifestations of entertainment, with sports being one of its main sources (RUDDOCK, 2010; WHANNEL, 2014). Sports can denote social events, represent local aspects and disseminate details of the culture of which they are part (WENNER, 2012; WHANNEL, 2014). This is the case of American football in relation to the United States of America (U.S.A.). The sport became the most popular in the country (ORIARD, 2007), and its major league, the National Football League (NFL), has sought to intensify its growth around the globe (SEIFERT, 2017).

As a brand, NFL has great economic value, being the world most lucrative league (OZANIAN, 2017). Besides, it has a huge social and cultural importance, since it has the capacity to direct social perceptions and to shape practices of the tradition (WENNER, 2012, 2014; WHANNEL, 2014), as well as counts with highly engaged fans that work as spreaders of the league (OATES and FURNESS, 2014).

The way of consuming American football has changed along with its main league. NFL has prioritizing not the fans who watch the games in the stadiums, but those who accompany the TV broadcasts (WENNER, 2014). It adheres the modern form of diffusing and consuming sports, according to Whannel (2014): media sports are broadcasted by large media conglomerates and impacted by their audience; sports of practice are popular by its large number of practitioners. The relationship between the two is dynamic: both societies can develop interest for media sports from the practice of them, as sports of practice gain adepts due to their media diffusion.

Media sports are considered global phenomena by the relevance that their broadcasts reach. They are not limited by geographic boundaries, however, some of them, even though are widespread in several markets of the world, cannot be considered global. This happens when their practice and rules are foreign to most individuals of a local culture (RUDDOCK, 2010; WHANNEL, 2014). It's the case of American football and NFL, despite its continued growth around the world, cannot be considered global yet. In most of the world, it does not have a majority audience, is considered alternative and exotic when compared to other sports, and its practice is incipient (SEIFERT, 2017).

This happens in Brazil, where the sport is yet not completely familiar. Nevertheless, the country has one of the major audiences of NFL in the world (ESPN BRASIL, 2015, MAGRI, 2018), reaching large audience (ESPN BRASIL, 2017). Brazil is NFL's second major international market, with nearly 20 million viewers, only behind Mexico, which borders US and hosts NFL games since 2005 (ESPN BRASIL, 2015).

NFL's Brazilian broadcast also counts with a significant engagement of fans through social media (ESPN BRASIL, 2017). Brazilian NFL viewers interact in social media during the league games broadcast. It occurs on Twitter hashtags created by the Brazilian ESPN channels for communication between fans and between them and the television station itself (MAGRI, 2018).

The messages published on the digital platform can be characterized as a proactivity consumer practice, since, when choosing to discuss the games between them, viewers are not restricted to the act of passive consuming an entertainment product. In this sense, fans are a productive consumer, by means of appropriating media texts, negotiating their meaning and spreading their content, what can be considered an exercise of resistance to the passive consumption reception model (JENKINS, 2008). Therefore, from a Consumer Culture Theory (CCT) point of view, fans resemble to the concept of prosumers (LEÃO and COSTA, 2018), since they take on tasks that usually belongs to producers, according to the dualistic model of production and consumption (RITZER, 2015; RITZER and JUNGERSON, 2010).

Such involvement indicates great identification of the fans with what they consume. Since consumption is one of the cultural practices of the contemporary world, it enables consumers to set up identities through social and symbolic resources that are provided and/or legitimized by market practices (ARNOULD and THOMPSON, 2005; BELK and CASOTTI, 2014). In this way, fan consumption practices can establish identities by the intensity of intellectual and emotional involvement with media products (GUSCHWAN, 2012).

These aspects lead us to the understanding that the interaction of the Brazilian NFL viewers, when observed as consumption practice, indicates identity formations. In line with this, in a recent review of CCT theoretical reverberations, Arnould and Thompson (2015) argue that such kind of consumption clusters are part of a subsystem of interconnected fragmented networks that provide resources for the identity work of consumers. 
Following Hall $(2012,2013,2014)$, we assume that such identity-working is cultural, referring to positions constituted by sociocultural relations that are incorporated by individuals into their own identity elaboration. This notion of cultural identity was conceived in the field of Cultural Studies as a way of conceiving the postmodern subject as a fragmented construction, capable of adhering to different culturally constituted identities, according to the different social fields in which one operates (WOODWARD, 2012).

From the understanding that consumer practices are capable of constituting cultural identities, present research aims analyzing how Brazilian NFL fans constitute cultural identities in their interactions on social media during the league games broadcast.

The research explores two layers of contribution for CCT studies: identity formation through the consumption of a foreign sport media by a local audience and the focus on this phenomenon through virtual social interactions. Despite identity narrative is an investigation topic already established in the field of CCT (see ARNOULD and THOMPSON, 2005, 2015), there is a lack of studies dealing with it regarding consumer virtual communities like fandoms. We follow Kozinets (2015) in the understanding that social networks social spaces as complex as other social life spheres. It is aligned to the Cultural Studies notions of deterritorialized culture, that takes off the conception of culture of its spatial bond (APPADURAI, 1996; HALL, 2014), and spaces of flows, that are arrangements - such as online environments -, configured for allowing social practices occur out of territories (CASTELLS, 2011).

\section{Fans as Productive Consumers}

Fans can be understood as singular consumers: on the one hand, they are characterized by the intensity of intellectual and emotional involvement they have with the products they admire; on the other hand, they are understood as capable of re-creating the mediatic text they receive (GUSCHWAN, 2012; LANIER and RADIER; FOWLER III, 2015). Hence, fans are commonly defined by the activities they perform (DUFFET, 2013).

Consumers active participation on re-signifying products or even producing new content based on them through technological appropriation is characterized into a phenomenon known as participatory culture (JENKINS, 2006). It happens due to consumers' convergence. They engage on interacting collective practices, becoming active members of communities (LANGLOIS, 2013; JENKINS, 2006).

Commonly, fans organize themselves in fandoms (COSTA and LEÃO, 2018). These are communities where they interact, developing, sharing and spreading their consumption experiences and practices (GUSCHWAN, 2012; JENKINS, FORD and GREEN, 2010). Besides, it is a social arrangement that is becoming habitual, thanks to the ascending entertainment industry and to the technological advances (HEWER, GANNON and CORDINA, 2015; JENKINS, 2006). Therefore, fandoms are consumer communities whose members are virtually related through common interest, even if they belong to other cultural worlds (KOZINETS, 2006).

Consumer communities are instances that can enable the constitution and maintenance of identities (LUEDICKE, THOMPSON and GIESLER, 2010). When consumers come together in community tribes and branded communities, they interact actively on the subject that unite them (BHATTACHARJEE, BERGER and MENON, 2014; COVA, PACE and SKÅLÉN, 2015). Consumer communities work on the identity of consumers since collective consumption practices constitute and exalt individual behavior and choices (LUEDICKE, THOMPSON and GIESLER, 2010; THOMAS, PRICE and SCHAU, 2013). They can be interpreted as imagined communities (ANDERSON, 1987), a sense of communion that generates a collective identity formed by a plurality of identities.

Thus, it is relevant to explore how fandoms can contribute to the identity-work. This practice becomes possible because fans shows a new way of exercising identities related to consumer practices, mostly through collaboration and citizenship acts (GUSCHWAN, 2012; JENKINS, 2008). Because fans are natural poachers, they use the fandom to articulate their political positions and sense of morality (JENKINS, 2013). Fandoms lead to a sense of community identity aligned to the media products they consume, but also capable of resist and contest them (FILLIS and MACKAY, 2014; HEWER, GANNON and CORDINA, 2015). 


\section{Consumer Identities}

Modern consumer practices allow people to envision an entrepreneurial idea of themselves. In those acts, one can formulate and express identities, insofar s/he behaves according to the group, community, network or environment to which is connect (BHATTACHARJEE, BERGER and MENON, 2014). This is facilitated by the plethora of resources available for consumer practices, which are conducive to identity construction. Consumption, therefore, plays an important role in the formulation of identity, as it carries symbolic meanings. Those significant representations define the groups which individual consumers belong to and establishes the relationship between identity and consumption in a social-symbolic way (BARTIKOWSKI and WALSH, 2015; BELK, 2014).

Thus, consumption practices have an ethnocentric capacity of legitimating the formation of identities. It works as a material and symbolic structure in which individuals construct identities based on the cultures s/he takes part (ZEUGNER-ROTH, ZABKAR and DIAMANTOPOULOS, 2015). This ethnocentrism of consumption legitimizes it for the formation of identities amid the culture that one takes part in, since its practices can reveal the existence of a material and symbolic social structure (ARNOULD and THOMPSON, 2015; COVA and COVA, 2014). Such identities allow consumers to present different facets of themselves, varying according to time, culture and social context (BELK, 2014).

Although noticeable at the individual level, consumer identities are elaborated from collectivities. So, identities are shared by individuals who believe to have common interests, so much that they come together to interact about them (ARVIDSSON and CALIANDRO, 2015). Collective identities often emerge by means of social interaction. Similarly, consumers group together in communities that enable them to virtually coexist, even though they belong to different cultural worlds (COVA and PACE, 2006; THOMAS, PRICE and SCHAU, 2013). So, consumer identities can be understood as resulting from an articulated work in the midst of fragmented consumption subsystems (ARNOULD and THOMPSON, 2015; COVA and COVA, 2014).

It is through consumption that fans establish their practices. They relate to the products they consume by the intensity of intellectual and emotional involvement with the media, capable of generating a commitment to it (GUSCHWAN, 2012). The identification of fans often occurs in fandoms (HEWER, GANNON and CORDINA, 2015), based on which it is possible to interpret the structures of fan culture as an indication of a new way of thinking about collaboration, as well as the constructing and exercising of identities (GUSCHWAN, 2012; JENKINS, 2008). This conception assumes consumer culture as a distributed and fluid network, in which its participants are aligned through reciprocal, self-organized and constantly reconfigured processes (ARNOULD and THOMPSON, 2015).

\section{Cultural Identities}

The theory of identity adopted in this study bases on the conceptualization developed in Cultural Studies, especially by Stuart Hall. Hall $(2012,2013,2014)$ defines cultural identity as a position that is characterized by a range of meanings inhering a cultural system and is constituted thanks to the sharing of mutual codes and signs. This is a social position resulting from a dialectic between the individual and the society in which one is inserted. Social processes shape, conserve or reshape cultural identities, and the notion of identity one holds influence the choose for the social structures and processes to take part in.

This dialectical process makes cultural identities to be marked by difference, being both singular and mutually dependent. Thus, a certain identity exists only to the extent that others also exist and are accessible to it, in a process of constitution by both affirmation and denial (HALL, 2013). While the classical identity approach pointed to a concept of oneness, the contemporary perspective indicates multiplicity, fluidity and fragmentation. It is the notion of difference that conceives cultural identity from the bond between the individual and the cultures to which s/he relates (HALL, 2012). Therefore, they are relational; forged and maintained through different spheres of social and cultural life (e.g., work, language, religion). This relationship, however, does not occur symmetrically, since a same identity is capable of articulating between different aspects of the same culture or between aspects of different cultures (HALL, 2012, 2014; SILVA, 2012).

Cultural identities, therefore, result from the individual-society dialectic. Social individuals participate in their collective constitution, then they embody them, instead of belonging them (HALL, 2014; WOODWARD, 2012). It happens in a dynamic and negotiable process in which individuals can belong to several identity positions simultaneously. So, it leads individuals to position themselves in the society (BAUMANN and GINGRICH, 2005; MIGUELES and ZANINI, 2018). Hence, cultural identities 
are based on alterity, since an identity exists only in function of its distinction from another, as well as from the identification of individuals in relation to them and between themselves (HALL, 2013, 2014).

Cultural identities derive from a meaning-making that occurs amid tensions and contradictions, based on cultural descriptions. This allows social actors to assume different identities, either due the different fields in which s/he moves in social life, or the very relationship between different identities (HALL, 2014; WOODWARD, 2012). Individuals become fragmented subjects, able to negotiate aspects of different cultures. The fragmentation of identities leads the individual to be in a continuous process of transition, in which cultural and social aspects are negotiated in their daily life (BAUMANN and GINGRICH, 2005; TILIO, 2009).

Those continuous negotiation show how postmodern identities are decentralized, fragmented and contradictory, revealing the displacement of individual identifications driven by different directions of the systems of meaning and cultural representation. Thus, there is a multiplicity of possible identities that individuals can be identified simultaneously and dynamically (HALL, 2014; OLIVEIRA and LEÃO, 2012). The construct resembles the postmodern notion of subjectivity, assumed to be formulated based on social practice. On the other it is argued that it has been accentuated by the process of globalization (HALL, 2014). Today's globalized world lead social systems to a cultural hybridism, resulted mainly from a range of identities that are exercised and subjected to cultural systems. In this context, the widespread adoption of new information and communication technologies (ICT) makes the physical barriers (i.e., borders, on-site contact) of different cultures that influence people's routine less and less visible (BESSI, SCHREIBER, PUFFAL et al., 2015; CASTELLS, 1999).

Du Gay (1997) inserts the question of cultural identity into a broader system that interconnects it with social representations, regulation, production and consumption. In line with Hall (2013), the author indicate how culture should be understood as a circuit, since it has major elements that are present in cultural processes, from the production of cultural artifacts to the representations to which they are associated. It is possible to produce identities from representations, or by the way cultural artifacts are consumed and, subsequently, from the power mechanisms that regulate its production and distribution.

Leão and colleagues (FRANCO and LEÃO, 2014; LEÃO, IANATONI and CAVALCANTI, 2015; LEÃO and MELLO, 2012; OLIVEIRA and LEÃO, 2012) articulate cultural identity as a consumer identity, inscribing consumption as a cultural system capable of producing and legitimizing cultural identities. When individuals interact in communities, they demarcate differences and particularities that reveal distinct identities (WOODWARD, 2012) that may or may not be aligned with the content produced by brands (LEÃO, IANATONI and CAVALCANTI, 2015). As Franco and Leão (2014) points out, the consumption provides a constitution and expression of cultural identities by the interaction between brands and consumers.

\section{METHODOLOGICAL PROCEDURES}

The research was not a verificationist design, based on theoretical constructs. Instead, theory was used in order to ground the research conceptualization and, mainly, as a means for interpreting the results. Thus, it was not taken as conceptual categories for the foundation of the empirical work (LEÃO, MELLO and VIEIRA, 2009), what is in line with the paradigm of interpretative research (LINCOLN, LYNHAM and GUBA, 2011).

The research was undertaken by netnography. The method is commonly used in studies that seek to understand cultural phenomena that occur through online interactions (BEGNINI, SANTOS, SEHNEM et al., 2019; IZOGO and JAYAWARDHENA, 2018). Strictly speaking, netnography is an adaptation of the ethnographic method to the virtual environment. It was developed to investigate consumer behavior in marketing studies by addressing cultures and communities mediated online (BARTL, KANNAN and STOCKINGER, 2016; HENRIQUES and PEREIRA, 2018).

Netnography was chosen because NFL's main consumer community in Brazil is mediated online in hashtags promoted by the ESPN channels. Those hashtags are posted on Twitter, one of most famous social networks in the world (VAN DJICK, 2013). As Kozinets $(2010,2015)$ points out, the method is appropriate for investigating forums, blogs and social networks. This is because it is able to capture social interaction particularities based the use of technologies that are not possible in ethnographies 
developed for anthropological purposes or conducted in physical locations (HAMILTON and ALEXANDER, 2017; SCARABOTO and PEREIRA, 2013).

In virtual communities, identities are constructed by means of material textual production (e.g. writings, photos, videos, avatars) (CHERNEV, HAMILTON and GAL, 2011; KOZINETS, 2010). This is how works face-to-face encounters in on-line environments (LEÃO, IANATONI and CAMARGO, 2015). The way individuals organize themselves in a network leads cultural connections to be not only social and economic, but fluid, flexible and dynamic (CASTELLS, 1999). Cultures that once had no contact are now accessed simultaneously in an established hybrid phenomenon, often in the virtual realm (CANCLINI, 2006; LÉVY, 1999). In this context, social interactions are mostly established in Computer Mediated Communications (CMC) (KOZINETS, 2015). Investigating such kind of phenomena allows the understanding of a wide variety of cultural effects, including individual and collective behavior and practices (BARTL, KANNAN and STOCKINGER, 2016), in a way that can only be seen in the online environments (i.e., avatars, memes) and that depend on the synchronicity in which data are collected (KOZINETS, 2010). Therefore, technological devices and the use of social networks enable qualitative research to deal with phenomena occurring in on-line environments (IACONO, SYMONDS and BROWN, 2016).

In order to guide our research, the approach proposed by Kozinets $(2006,2010,2015)$ was adopted. It has been widely adopted in marketing and mainly in consumer research. The method is proposed in three stages, that follows.

Entrée Cultural. A process in which researchers become naturalized to the culture under investigation in order to perceive details that only members of the community are capable of. For our research, we opted to observe the interactions between Brazilian NFL fans through the exchange of messages on Twitter. They are stimulated by the ESPN channels for local broadcasts of the games. The media corporation was the first Pay TV channel to broadcast the NFL games in Brazil, in September 1992, holding exclusive rights in the country since 2017 (FIRMINO, 2018; FRANCISCHINI, 2018). This stage happened naturally, since both researchers have been NFL viewers since 2009. One of them is active member of the community investigated since 2011, same period in which is also a player on the American football Brazilian league.

Data collection. Procedure for archiving the observed online interactions. Data collection works by archiving both the text of mediated interaction in the online community, and other content that are part of the observed interactions (i.e. photos, videos). It is a process that is usually done in different moments, be it because data analysis and interpretation may require new data to be collected, either to look for saturation level. This stage can also be complemented by field notes. In the period our investigation, the community interacted mainly during the game broadcasts. Four hashtags released by the Brazilian ESPN were monitored, whose tweets were saved and archived: \#TudoPelaNFL, \#PlayOffsNFLnaESPN and \#SuperBowlnaESPN (2016-2017 season) and \#NFLnaESPN (2017-2018 season). Still, the games broadcasted by the Brazilian ESPN (119 in the first season and 141 in the second) were recorded, in order to serve as an immediate context for the analysis of the fan comments.

Data analysis. The last stage can be divided in steps of analytical procedures: codification, reflection, abstraction, comparison, verification, refinement, theoretical generalization and (possibly) theorizing. We organized such steps in three moments of analysis. First, we performed a round of analysis to establish provisional codes, as well as to classify and hierarchize the data collected. Then, we filter the data to generate clearer identifications and relations that have been revealed as broader categories. Finally, we interpret such categories in light of the literature. Yet, this analysis had an inductive character at the first season, since literature served as analytical lenses instead of a priori categories. During the second season, a partially deductive approach took place, since it started from the categories inferred in the first period, maintaining, however, the process open to the identification of new codes and categories.

To meet quality criteria of qualitative research, we adopted criteria to netnography pointed by Kozinets (2015), regarding data saturation, axiological arguments set in the cultural entrée, researchers' reflexivity and respect to the observed praxis. Also, ethical issues were considered, following Kozinets (2006). We did not cause any harm to the community analyzed, since the messages collected were produced in the public domain, a social network with open access for all who accessed the referred hashtags, and we do not reveal members identities. 


\section{RESULTS AND DISCUSSION}

Our analysis revealed nine codes, which were organized into three categories. In the following, these are discussed. For such, we present excerpts from the research corpus to illustrate the empirical context described and reflections derived from the literature of Cultural Studies and CCT on cultural identity and consumer identity, respectively, due to the semi-inductive character of the research.

\section{Brazilian nationalism in the NFL consumption}

As a first category, we identify how Brazilian NFL fans establish associations between their country and the league as a way of valuing themselves as audience. In a consumer research perspective, a national identity is guided by the recognition that brands, goods or services are exponents of a nation with which consumers identify (KEILLOR and HULT, 1999; ZEUGNER-ROTH, ZABKAR and DIAMANTOPOULOS, 2015). In the context of cultural identities, Hall (2014) points that nationalism is the shared notion of individuals and groups that recognize and establish characteristics in common, leading to the idea of belonging to a nation (HALL, 2014).

A first code in this category reveals the identification of the Brazilian NFL fans with Cairo Santos, the only Brazilian player on the league. His participation on the NFL arouse great repercussion, making him a popular figure in the country. Tweets collected over different games featuring Cairo Santos in the 2016-2017 season demonstrate how Brazilian fans feel represented as nation by having a player of their homeland in the NFL. They write about the player with affection and intimacy by calling him "Cairão da Massa" (i.e., Big Cairo from the Mass), a nickname that exalts his popularity among Brazilian aficionados. Many tweets manifest he represents the country in the NFL and highlight that the whole country eager to see him in action on the matches. This commotion led him to be nominated as NFL ambassador in Brazil since 2016. A good example of this is a tweet posted on September 7, 2017, during the season-opening game, when a league fan types "Cairão da Massa, hero of Brazilian people \#ChiefsKingdom \#NFLnaESPN".

Brazilian fans cheer for the player as if for a sports team that represents the nation internationally. This feeling is transferred to the team he plays, but only for fidelity to him. This became evident when he was dismissed from Kansas City Chiefs, his first team on NFL, after an injury sustained in the third week of the 2017-2018 season. Previously supporting the team, Brazilian NFL fans got angry with the Chiefs. Tweets published on the occasion provoked the former team of the athlete, stating that they messed with the wrong people by dispensing the only Brazilian in the league. Countless Brazilian fans started to register that, from that moment on, they shall cheer against the Kansas City Chiefs. Innumerous messages were posted wishing for bad lucky to team and the player who replaced Cairo Santos.

For those who said the Brazilian plague is not working, this is because the Chiefs released Cairão da Massa. MY TITANS ARE GIANTS [January 6, 2018].

\#NFLnaESPN @everaldomarques and @ pauloantunes this is a lot of zica in Butker from Brazil. lol In honor to Cairão da Massa [January 6, 2018].

In subsequent seasons, Cairo Santos suffered an injury that caused him to change teams (i.e., Chicago Bears, Los Angeles Rams) or even run out of contract. During a playoff game, in a period when he was unemployed, a fan remembers to complain, following a kicker's bad play: "Where is Cairão da Massa in NFL? Where? \#NFLnaESPN \#MINvsGB" [September 16, 2018].

Later, when he was hired by the Los Angeles Rams to replace an injured player just for a few weeks, a fan celebrates: "Now Los Angeles Rams is my team since I was a child. Go Cairo Santos!" [October 2, 2018]. Two weeks later, when the Brazilian player was dismissed, another fan protests: "\#NFLnaESPN Cairão da Massa dismissed by the RAMS? [After] The guy rules against Seattle and the Broncos? How is this possible?" [October 17, 2018].

In another evidence of nationalism, next code highlights the fact the main league player to be married to a Brazilian celebrity. Brazilian international supermodel Gisele Bündchen is the wife of Tom Brady, New England Patriots player and one of the greatest in NFL history. Due to this relationship, Brazilian NFL fans nicknamed him "Giselo" - a masculine form to his wife 
name. This witty kidding reveals a bond of intimacy constructed by the fans with the athlete based on their marital relation with a Brazilian citizen. Good-natured tweets associate the athlete's good performances with his marriage to Bündchen. Besides, his nickname is used to exalt these performances, as well as trolling the model when his husband's team is losing. In a tweet published on January 13, 2018, a fan plays: “@CurtiAntony one question, Gisele Bündchen is Brazilian, she's married to Giselo, right? So Giselo also is Brazilian, correct?? Why doesn't he play for the Brazilian team? Has anyone invited him yet?? \#NFLnaESPN \#NFLPlayoffs". In another message, after Patriots lose a championship game, one fan posted: "Suck it Giselo, today will not happen \#SuperBowInaESPN \#FlyEaglesFly" [February 4, 2018]. In another situation, a fan puts in check if Giselo or Cairo Santos best represents Brazil on NFL: “\#NFLnaESPN starting with Patriots of Giselo vs. Chiefs of Brazilian Cairo Santos. Which one we will support?" [September 7, 2017].

Finally, the third code reveals the claim of Brazilian fans of deserving an NFL game hosted in Brazil. They use the fact of Brazil to be the league's second largest world audience outside U.S.A. to demand the league attention. Countless messages over the seasons illustrate this. A message posted during the game between Oakland Raiders and Houston Texans played in Mexico City on November 21, 2016, extols: "We can see the happiness of Mexican fans in this \#MNF I hope someday we can see this feeling here in Brazil \#TudoPelaNFL". The message evoke that Brazilian are a cheerful people and passionate for NFL as they are. On the other hand, supporting the fans' clamor following the match between Cincinnati Bengals and Washington Redskins in London on October 30, 2016, like in the message: "NFL cross the ocean to play in London, a cold land and no-loud support. Why don't came south to Brazil? There they gonna have loud! \#TudoPelaNFL". Yet, the official Twitter profile of ESPN Brazil (@mundoespn) also pleaded for a game in the country: “We also want a game here in Brazil, you can hear mrs. @NFL @NFLBrasil !! We deserve it and do all for NFL" (\#TudoPelaNFL) [November 21, 2016].

\section{Locality exaltation in the NFL enjoyment}

Second category indicates how different Brazilian locations, especially those less noticeable and more remote from the major urban centers, are highlighted and valued by the Brazilian audience in the wake of the broadcast of the games. Consumer research has identified that consumers work on spatially located identities (CHERNEV, HAMILTON and GAL, 2011; LUEDICKE, THOMPSON and GIESLER, 2010). Hall (2014), in turn, allege that one of the ways cultural identity manifests is through the place of birth, since it defines particular beliefs and values, as well as performs as point of resistance to the process of homogenizing globalization.

One code of this category indicates an exaltation of local American football teams. Brazilian fans introduce to the community American football teams, from their cities or states, in which they play or cheer. Viewers usually highlight the team names, since commonly they are formed by their city of origin name associated with a local characteristic, just like happens in NFL, as a way to value such locations. Examples flourish on the tweets. In a message, a fan declares being fan of the Maceió Marechais (i.e., Maceió Marshals): "Today is Thurdays Night Football, and saturday is the day of National League, \#MaceióMarecheais towards to one more victory! \#GoMarechais \#TudoPelaNFL" [Setember 15, 2016]. The team name alludes to the first two presidents of Brazil. Both had the highest patent of the Army. One of them was born at the city of Maceió, and the other in a city at Alagoas, state whereof Maceió is the capital. In another message, a viewer asks to the ESPN staff to send a hug to the Goiânia Rednecks fans: "\#TudoPelaNFL sent a hug to Goiânia Rednecks fans!!! We going to win National League” [October 2, 2016]. The team was named in reference to the U.S.A. Old West, due to the fact the city of Goiânia is located at the CenterWest region of Brazil.

Another kind of exaltation highlights the locales watching the NFL. Fans use the social media as representatives of their localities to the ESPN staff and the other league fans. From all over the country, messages make it a point to register from which cities or states the fans are watching the games. Those tweets include the cited regions in the league's national audience map and celebrate them and its fellow citizens, mainly asking to the ESPN staff to greet fans from these locations. Such messages emanate from a profusion of localities, ranging from large urban centers to inner cities of less affluent regions of the country. A tweet published on November 13, 2017, illustrates this: "Chiapetta - RS is certainly the smallest connected city in \#NFLNAESPN with 4044 people according to the last census". Another one not only exalts the city, but also alludes to the local football team: "It's Sunday time in the city of Doce, Nerópolis - GO. We are friend of the Goiânia RedNecks \#NFLnaESPN". 
The last code of this category highlights the impact of Brazilian time zones on the NFL enjoyment. During part of the NFL season, game schedules are affected by the end of DST in the U.S.A. and its beginning in Brazil. In the middle of the regular season, the routine of Brazilian viewers is changed, especially regarding the night games. Broadcast schedules are delayed in two hours to the main cities of the country, located in South and Southeast Brazil. This change makes viewers from the Northeast and the North to watch the games earlier, what is highlighted as a great advantage. In a tweet a fan highlights this point: "The advantage of living in Acre is it is still 23:00 (just that advantage) lol \#tudopelaNFL" [November 7, 2016]. In a reply of the message, another fan, who lives in southwest region, brings a good illustration that show the Brazilian time zone map, highlighting the privileges of the north region. Jokingly, the sender says "Why you do this? A hug to all Acre people! Always assiduous in \#TudoPelaNFL" [November 7, 2016], revealing be envy of its residents, since the state is not affected by the time change for being in the same time zone of the U.S.A. East Coast.

\section{Social minorities in the Brazilian NFL audience}

The last category reveals that, despite American football public is associated with heterosexual men, Brazilian NFL audience counts on women and homosexual. Hall (2017) understands that gender identities are not natural conceptions, but social constructs constituted by political, economic, and socio-cultural forces over time and spatially demarcated. Appropriation and re-signification of consumer practices can contribute to the feminine identity, insofar they propitiate resistance to structures of dominant social meanings (FUNG, 2002; MANSVELT, BREHENY and STEPHENS, 2015). The same can be said regarding gay identity, since practices of consumption are used to naturalize and legitimize this way of life (KATES, 2002). However, such practices made by a socially stigmatized public tends to be repudiated by plots of consumers (MANSVELT, BREHENY and STEPHENS, 2015).

The seventh code overall demonstrates the female activism in the Brazilian NFL fandom. Women show off their participation in the community of fans and disclosure NFL specialized profiles managed exclusively by the female audience. ESPN broadcast staff usually praises the feminine participation on the hashtags and, at the 2016-2017 season beginning, reported that about $45 \%$ of the NFL audience in the country is comprised of the female audience. In the wake of this announcement, several messages highlighted that watching NFL in Brazil is a habitual thing for both genders. On September 8, 2016, a fan repeated the data released during the tweet broadcast: " $45 \%$ of the audience only women, we are increasingly winning the world \#TudoPelaNFL".

An emblematic day for female audience was October 9, 2016, when the ESPN aired a documentary produced by the NFL before a Sunday Night Football, the league's highest-rating weekly game. The thirty-minute film show how American football, and the NFL in particular, has been striving to reach the female audience. Among the various tweets published that night, women's growth in sport audience is celebrated as a victory over prejudice, emphasizing that the world does not belong to men. A tweet can exemplify this sense: "That's right! Women growing up in football! Overcoming Prejudice, the World Is Not Men's \#AllPelaNFL".

In another emblematic event, female audience vehemently echoed two occurrences in the game between Los Angeles Chargers versus Denver Broncos on September 11, 2017. For the first time, a woman narrated an NFL game on the U.S.A. TV. Simultaneously, Paula Ivoglo, a member of the exclusively-women managed NFL @nfldebolsa profile, was the first commentator to participate in a Brazilian NFL broadcast, later permanently integrated into the ESPN team. The commotion about this feat resulted in a large number of tweets on the subjects that evening, with female fans emphasizing how they felt represented.

Warn the misogynist that on ESPN's broadcast there is a woman in the \#NFLnaESPN [September 11, 2017].

Is there a woman narrating the US game and another commenting on Brazilian ESPN? THAT'S MY MOMENT!!!! \#NFLnaESPN [September 11, 2017].

Well, better conform yourself: woman's place is where she wants. There will be women narrating, playing, commenting, WILL HAVE WOMAN IN EVERY PLACE \#NFLnaESPN [September 13, 2017].

In another tweet, a male fan supports this trend: "Very cool to hear a female voice commenting football. More women in the NFL \#NFLnaESPN" [September 11, 2017]. 
The following code revolves around gay representation among the Brazilian NFL audience. This public emerged along with the huge repercussion of Lady Gaga's show at the Super Bowl LI halftime on February 5, 2017. The artist is a LGBT icon and her performance ended up luring this audience. On that evening, Gaga's fans made it a point to register their presence as part of the audience tuned in the broadcast. Additionally, large numbers of viewers reported that show was their gateway to the league. Tweets praised the presence of the gay public in the audience of the league and many messages pointed that a show of a LGBT icon brings representativeness in a sport in which the ethnicity, age and shape of the athletes are already diverse.

Two messages can work as good examples:

Am I the only one who came to see Lady Gaga's show and now is worried about the match result? \#SuperBowlnaESPN [February 5, 2017].

Today is the day ESPN will have the best audience: the gay and the little monster, enjoy this special day \#SuperBowlnaESPN. [February 5, 2017].

Paddling against the tide, the last code evidences how homophobia is perpetuated by part of Brazilian NFL audience. As a reaction of gay audience messages, part of male heterosexual audience criticized Lady Gaga's choosing for the halftime show, as well as the presence of gays in the fandom. Many tweets disdained and ridiculed the LGBT audience tuned on the broadcast and argued that the virility of American football does not match with them nor either with the artist's performance. They still made "jokes" on whether men or their sons were enjoying the show, as a way of representing it as a gay behavior.

Tweets posted in this moment can illustrated this code:

American football, a male alpha sport that oozes testosterone, which has fight and blood, putting Lady Gaga to play. \#SuperBowlnaESPN [February 5, 2017].

If your son decides to watch \#SuperBowInaESPN for the first time and are shaking his feet at Lady Gaga music, I have a bad new to you [February 5, 2017].

Other tweets in this tone were also seen. A message posted on October 26, 2017, illustrates this situation well in criticizing the quality of Paula Ivogllo's comments says “\#NFLnaESPN ESPN will have quota for gay, northeastern, Indian, black, Chinese and Bolivian too?".

\section{FINAL CONSIDERATIONS}

Returning to the research objective, we can attest that Brazilian NFL fans constitute cultural identities in their interactions on social media during the league games broadcast by negotiating the production of meanings from the contents received. This is done not only in relation to the specific content of the games, but also the knowledge and context that fans have about the league and even about issues extrapolating the game.

NFL is perceived both as intrinsic to the U.S.A. culture and to masculinity, due its athletic virility. These aspects became the basis of how the league was re-signified by the Brazilian fans in the formation of their consumer cultural identities. On the one hand, our findings reveal identities strongly related to the notion of place, either in a sense of nationalism or in valuing particular localities. On the other hand, they show how identities different of the hetero masculine are presented.

The national identity of Brazilian fans is exercised by exalting aspects of their homeland regarding the NFL. Either by means of a fellow countryman player, the marital relationship of the greatest star of the sport, or the wish of hosting NFL games, Brazilian fans proclaim how relevant the country is for the league enjoyment. This articulation projects an idealized image of the nation. Specifically, it reveals the relevant role of a consumer characteristic in his relationship with the brand consumed, making a typically American sport to be enjoyed based on a multiculturalist negotiation. The valuing of compatriots (codes 1 and 2) and the wish to have the country taking part in the league (code 3) show, respectively, a consumer national heritage and an ethnocentrism of consumption (KEILLOR and HULT, 1999). Both aspects are consistent with nationalism as defined by Hall (2014): a cultural identity capable of encompassing characteristics and desires shared by individuals or groups that establish the sense of belonging to a nation. 
While the first cultural identity identified refers to a collective sense of belonging to a nation, the second singles out the belonging to a certain locality. By extolling the places where they live or were born, the fans demonstrate the importance of the locales in a continental country. Valuing certain regions in the Brazilian NFL fandom is an emblematic behavior of demarcating the social and economic differences that usually reduce the country to its more developed poles. Thus, despite the interactions occur around a foreign cultural product, we identify tensions that are inherent to the differences existing in the country itself. The three codes of this category reveal how peculiarities (i.e. cultural aspects, local exaltation or its time zone) of a locale affect the experience of consumption (CHERNEV, HAMILTON and GAL, 2011; LUEDICKE, THOMPSON and GIESLER, 2010). Such concept resonates that a cultural identity manifests the place where one lives or was born, as well as beliefs and values that resist the globalization (HALL, 2014).

Finally, NFL consumption in Brazil provides ways of representativeness for two identities that are not usually associated to sports consumption: female and gay. However, while women seem to be engaging in the sport fanity through identity demarcation, the critical incident that attracted the gay audience may or may not have ramifications in their engagement to the sport. These positionings seem to be influenced by the male behavior regarding them. While women seem to have a good acceptance among the male audience, the same does not happen with the gays, who comes to be harassed, in a prejudiced behavior that seems to look for preserve the hetero-masculine identity strongly associated with sports. Both cases of women expressing social relevance and notoriety through consumption practices (FUNG, 2002; MANSVELT, BREHENY and STEPHENS, 2015) and gays seeking for inclusion in typically heterosexual consumer niches (KATES, 2002), even when being stigmatized (MANSVELT, BREHENY and STEPHENS, 2015) reveal identities in a process of social constructing. These dynamics reveals tensions and conformities, highlighting the social construction of gender and the appropriation of the product as a symbolic element of this process. It is precisely on this issue that Hall (2017) defines how cultural identities are constituted by political, economic, and socio-cultural forces.

The present research brings the reflection of how the interactivity in social media enables not only the expression, but also the formulation, legitimation and maintenance of cultural identities established in consumer practices. In doing so with reference to a media sport, points out how global entertainment plays an important role in the configuration of contemporary identities. The Interdisciplinar theoretical approach and the assumption of the NFL as a media product and its consumers as fans, broadens the scope of CCT research between cultures and market ideologies and the formation of identities (ARNOULD and THOMPSON, 2007).

The choice made for the research design can be characterized both as a limit and a limitation, since only the part of the Brazilian NFL audience that engages through social media was observed. As a limitation, it excludes the portion of the audience that does not express their opinions on social media. As a limit, it is an incidental choice, aligned with the research problem, which focuses on the consumers engaged in participatory culture (JENKINS, 2008). Another limitation concerns the temporality of data collection, reduced to two NFL seasons, which is justified by the feasibility of the work.

Finally, we leave as a suggestion for future research the investigation of Brazilian fans of other American sports, such as the Major League Baseball (MLB) and the National Basketball Association (NBA), engaged in social media. It could provide comparisons with our results. Moreover, based on the findings presented, researches could focus on the formation of cultural identities in the enjoyment of global media products, as well as on the formation of identities related to social minorities in pop culture consumption.

\section{ACKNOWLEDGEMENTS}

National Council for Scientific and Technological Development (CNPq) supported the research.

Coordination for the Improvement of Higher Education Personnel (CAPES) supports the graduate program to which the researchers are affiliated. 


\section{REFERENCES}

ANDERSON, B. Imagined Communities: reflections on the origin and spread of nationalism. London: Verso. 1987.

APPADURAI, A. Modernity at Large: cultural dimensions of globalization. Minneapolis: University of Minnesota Press, 1996.

ARNOULD, E. J.; THOMPSON, C. J. Consumer culture theory (CCT): twenty years of research. Journal of Consumer Research, v. 31, n. 4, p. 868-882, 2005.

ARNOULD, E. J.; THOMPSON, C. J. Consumer Culture Theory (and we really mean theoretics): dilemmas and opportunities posed by an academic branding strategy. In: BELK, R. W.; SHERRY, J. F. (Eds.). Research in Consumer Behavior: consumer culture theory. Oxford: Elsevier, 2007. (Research in Consumer Behavior, v. 11). p. 3-22

ARNOULD, E. J.; THOMPSON, C. J. Introduction: Consumer Culture Theory: ten years gone (and beyond). In: THYROFF, A. E.; MURRAY, J. B.; BELK, R. W. B. (Eds.) Consumer Culture Theory. Bingley: Emerald Group Publishing Limited, 2015. (Research in Consumer Behavior, v. 17). p. 1-21.

ARVIDSSON, A.; CALIANDRO, A. Brand Public. Journal of Consumer Research, v. 42, n. 5, p. 727-748, 2015.

BARTIKOWSKI, B.; WALSH, G. Attitude toward cultural diversity: A test of identity-related antecedents and purchasing consequences. Journal of Business Research, v. 68, n. 3, p. 526-533, 2015.

BARTL, M.; KANNAN, V. K.; STOCKINGER, H. A Review and Analysis of Literature on Netnography Research. International Journal of Technology Marketing, v. 11, n. 2, p. 165-196, 2016.

BAUMANN, G; GINGRICH, A (Ed.). Grammars of identity/alterity: a structural approach. New York: Berghahn Books, 2005.

BEGNINI, S. et al. Capitalismo consciente: uma análise netnográfica em grupos da rede social LinkedIn. Cadernos EBAPE.BR, Rio de Janeiro, v. 17, n. 2, p. 277-293, 2019.

BELK, R. Digital consumption and the extended self. Journal of Marketing Management, v. 30, n. 11/12, p. 1101-1118, 2014.

BELK, R.; CASOTTI, L. M. Pesquisa Etnográfica em Marketing: Passado, Presente e Futuros Possíveis. REMark - Revista Brasileira de Marketing, v. 13, n. 6, p. 1-17, 2014.

BESSI, V. G. et al. As Tecnologias de Informação e Comunicação e sua Influência na Vivência Espaço-Temporal de Trabalhadores Bancários. Cadernos EBAPE.BR, Rio de Janeiro, v. 13, n. 4, p. 776-794, 2015.

BHATTACHARJEE, A.; BERGER, J.; MENON, G. When Identity Marketing Backfires: Consumer Agency in Identity Expression. Journal of Consumer Research, v. 41, n. 4, p. 294-310, 2014.

CASTELLS, M. O Poder da Identidade. São Paulo: Paz e Terra, 1999. (A era da informação: economia, sociedade e cultura, v. 2).

CASTELLS, M. The Rise of the Network Society. The Information age: economy, society and culture (2. ed.). Oxford: Wiley Blackwell, 2011.

CHERNEV, A.; HAMILTON, R.; GAL, D. Competing for Consumer Identity: Limits to Self-Expression and the Perils of Lifestyle Branding. Journal of Marketing, v. 75, n. 3, p. 66-82, 2011.
COVA, B.; COVA, V. On the road to prosumption: marketing discourse and the development of consumer competencies. Consumption Markets \& Culture, v. 15, n. 2, p. 149-168, 2012

COVA, B.; COVA, V. CCT applied research and the limits of consumers heroicisation. Journal of Marketing Management, v. 30, n. 11-12, p. 1086-1100, 2014.

COVA, B.; PACE, S. Brand community of convenience products: new forms of customer empowerment - the case of "my Nutella The Community". European Journal of Marketing, v. 40, n. 9-10, p. 1087-1105, 2006.

COVA, B.; PACE, S.; SKÅLÉN, P. Brand volunteering: Value co-creation with unpaid consumers. Marketing Theory, v. 15, n. 4, p. 465-485, 2015.

COSTA, F. Z. N.; LEÃO, A. L. M. S. A vida organizada dos fãs de Harry Potter. O\&S, v. 25, n. 84, p. 122-154, 2018.

DUFFETT, M. Understanding fandom: an introduction to the study of media fan culture. London: Bloomsbury Publishing, 2013.

DU GAY, P. Production of culture/cultures of production. London: Sage, 1997.

ESPN BRASIL. Brasil é 2o país com mais fãs de NFL fora dos EUA, diz pesquisa. ESPN, São Paulo, Feb. 04, 2015. Available at: <http://espn. uol.com.br/noticia/481491_brasil-e-2-pais-com-mais-fas-de-nfl-forados-eua-diz-pesquisa>. Accessed on: Nov. 28, 2018.

ESPN BRASIL. ESPN quebra recorde histórico com transmissão exclusiva do Super Bowl na TV por assinatura. ESPN, São Paulo, July 07, 2017. Available at: <http://espn.uol.com.br/noticia/669285_espn-quebrarecorde-historico-com-transmissao-exclusiva-do-super-bowl-na-tvpor-assinatura>. Accessed on: Nov. 28, 2018.

FILLIS, I.; MACKAY, C. Moving beyond fan typologies: The impact of social integration on team loyalty in football. Journal of Marketing Management 30, n. 3-4, p. 334-363, 2014.

FIRMINO, A. Conheça a história das transmissões do Super Bowl no Brasil. A Tribuna, Santos, Feb. 04, 2018. Available at: <https://www. atribuna.com.br/2.713/conheça-a-história-das-transmissões-dosuper-bowl-no-brasil-1.43517> Acessed on: Aug. 05, 2018.

FRANCISCHINI, G. Detentora dos direitos da NFL no Brasil, ESPN transmitirá mais de 140 partidas em nova temporada da Liga. ESPN, São Paulo, Sept. 05, 2018. Available at: <https://espnpressroom. com/brazil/press-releases/2018/09/detentora-dos-direitos-da-nfl-nobrasil-espn-transmitira-mais-de-140-partidas-em-nova-temporadada-liga/> Acessed on: Aug. 05, 2018.

FRANCO, S. M.; LEÃO, A. L. M. As "marcas" de uma nova fronteira vinícola: identidade cultural das marcas de vinhos do Vale do São Francisco. RECADM, v. 13, n. 3, p. 393-413, 2014.

FUNG, A. Women's Magazines: Construction of Identities and Cultural Consumption in Hong Kong. Consumption Markets \& Culture, v. 5, n. 4, p. 321-336, 2002.

GUSCHWAN, M. Fandom, brandom and the limits of participatory culture. Journal of Consumer Culture, v. 12, n. 1, p. 19-40, 2012.

HALL, S. Quem precisa de identidade? In SILVA, T. T. (Ed.). Identidade e diferença: a perspectiva dos estudos culturais. Petrópolis: Vozes, 2012. 
HALL, S. The work of representation. In: HALL, S.; NIXON, S. (Eds.), Representation: Cultural representation and cultural signifying practices (2. ed.). Thousand Oaks: Sage, 2013.

HALL, S. A identidade cultural na pós-modernidade. (12. ed.). Rio de Janeiro: DP\&A, 2014.

HALL, S. The whites of their eyes: racist ideologies and the media. In: DINES, G.; HUME, J. M. (Eds.). Gender, race, and class in media: a critical reader. (5. ed.). Thousand Oaks: Sage, 2017.

HAMILTON, K.; ALEXANDER, M. Spatial, temporal and social dimensions of a "destination-in-motion." European Journal of Marketing, v. 51, n. 11/12, p. 2101-2117, 2017.

HENRIQUES, F. M.; PEREIRA, S. J. N. Autenticidade e Consumo de Rock Clássico: uma Netnografia no Facebook. REAd - Revista Eletrônica de Administração, v. 24, n. 1, p. 1-29, 2018.

HEWER, P.; GANNON, M.; CORDINA, R. Discordant fandom and global football brands: 'Let the people sing'. Journal of Consumer Culture, v. 17, n. 3, p. 600-619, 2015.

IACONO, V. L.; SYMONDS, P.; BROWN, D. H. K. Skype as a tool for qualitative research interviews. Sociological Research Online, v. 21, n. 2, p. 1-15, 2016.

IZOGO, E. E.; JAYAWARDHENA, C. Online shopping experience in an emerging e-retailing market. Journal of Research in Interactive Marketing, v. 12, n. 2, p. 193-214, 2018.

JENKINS, H. Fans, Bloggers, and Gamers: exploring participatory culture. New York: NYU Press, 2006.

JENKINS, H. Convergence culture: where old and new media collide. New York: New York University Press, 2008.

JENKINS, H. Textual Poachers: television fans and participatory culture. New York: Routledge, 2013.

JENKINS, H.; FORD, S.; GREEN, J. Spreadable media: creating value and meaning in a networked culture. NYU Press, New York, NY, 2013.

KATES, S. The Protean Quality of Subcultural Consumption: An Ethnographic Account of Gay Consumers. Journal of Consumer Research, v. 29, n. 3, p. 383-399, 2002.

KEILLOR, B. D.; HULT, G. T. M. A five-country study of national identity: implications for international marketing research and practice. International Marketing Review, v. 16, n. 1, p. 65-84, 1999.

KOZINETS, R. V. Netnography 2.0. In: R. W. BELK (Ed.). Handbook of qualitative research methods in marketing. Cheltenham: Edward Edgar, 2006.

KOZINETS, R.V. Netnography: doing ethnographic research online. London: Sage, 2010.

KOZINETS, R.V. Netnography: redefined. London: Sage, 2015.

LANGLOIS, G. Participatory Culture and the New Governance of Communication: The Paradox of Participatory Media. Television \& New Media, v. 14, n. 2, p. 91-105, 2013.

LANIER JR., C. D.; RADIER, C. S.; FOWLER III, A. S. Ambiguity and fandom: the (meaningless) consumption and production of popular culture. Consumer Culture Theory, v. 17, p. 275-293, 2015.
LEÃO, A. L. M. de S.; COSTA, F. Z. N. Agenciados pelo desejo: O consumo produtivo dos Potterheads. RAE-Revista de Administração de Empresas, São Paulo, v. 58, n. 1, p. 74-86, 2018.

LEÃO, A. L. M. de S.; MELLO, S. C. Significação das marcas pelos consumidores em suas interações sociais: recurso simbólico de expressões de identidade cultural. REMark - Revista Brasileira de Marketing, v. 11, n. 1, p. 47-74, 2012.

LEÃO, A. L. M. de S.; MELLO, S. C.; VIEIRA, R. S. G. O papel da teoria no método de pesquisa em Administração. Revista Organizações em Contexto, v. 5, n. 10, p. 1-16, 2009.

LEÃO, A. L. M. de S.; IANATONI, T.; CAVALCANTI, R. T. Identidades Culturais de Consumidores da Pitú em sua Comunidade de Marca: Uma Netnografia da Comunicação. Revista de Gestão Organizacional, v. 8 , n. 2 , p. $60-81,2015$

LÉVY, P. Cibercultura. São Paulo: Editora 34, 1999.

LINCOLN, Y.; LYNHAM, S.; GUBA, E. Paradigmatic controversies, contradictions, and emerging confluences, revisited. In N. K. DENZIN; Y. S. LINCOLN (Eds.). SAGE handbook of qualitative research. (4. ed.). Thousand Oaks: Sage, 2011. p. 97-128.

LUEDICKE, M. K.; THOMPSON, C. J.; GIESLER, M. Consumer Identity Work as Moral Protagonism: How Myth and Ideology Animate a Brand-Mediated Moral Conflict. Journal of Consumer Research, v. 36, n. 6, p. 1016-1032, 2010.

MAGRI, D. Muito além do Super Bowl: futebol americano cresce em audiência e praticantes no Brasil. El País, São Paulo, Feb 04, 2018. Available at: <https://brasil.elpais.com/brasil/2018/02/01/ deportes/1517507665_087170.html>. Acessed on: Nov. 28, 2018.

MANSVELT, J.; BREHENY, M.; STEPHENS, C. Still being 'Mother'? Consumption and identity practices for women in later life. Journal of Consumer Culture, v. 17, n. 2, p. 340-358, 2015.

MIGUELES, C. P.; ZANINI, M. T. F. A natureza volitiva da motivação e a criatividade cultural: uma investigação antropológica. Cadernos EBAPE.BR, Rio de Janeiro, v. 16, n. 3, p. 355-366, 2018.

OATES, T. P.; FURNESS, Z. (Eds.) The NFL: critical and cultural perspectives. Philadelphia: Temple University Press, 2014.

OLIVEIRA, M. A. C.; LEÃO, A. L. M. de S. Sendo aos olhos do outro: o papel da alteridade na construção da identidade metrossexual. Revista de Administração - RAUSP, São Paulo, v. 47, n. 2, p. 264-274, 2012.

ORIARD, M. Brand NFL: Making and selling America's favorite sport. University of North Carolina Press, Chapel Hill, North Carolina, NC, 2007.

OZANIAN, M. The Forbes Fab 40: The World's Most Valuable Sports Brands 2017. Forbes, New York, Oct. 04, 2017. Available at: <https:// www.forbes.com/sites/mikeozanian/2017/10/24/the-forbes-fab40-the-worlds-most-valuable-sports-brands-2017/\#628ecc693b84>. Acessed on: Nov. 28, 2018.

RITZER, G. Automating prosumption: The decline of the prosumer and the rise of the prosuming machines. Journal of Consumer Culture, v. 15, n. 3, p. 407-424, 2015.

RITZER, G.; JURGENSON, N. Production, Consumption, Prosumption: The nature of capitalism in the age of the digital 'prosumer'. Journal of Consumer Culture, v. 10, n. 1, p. 13-36, 2010. 
RUDDOCK, A. Contradictions in media sport culture: The reinscription of football supporter traditions through online media. European Journal of Cultural Studies, v. 13, n. 3, p, 323-339, 2010.

SCARABOTO, D.; PEREIRA, S. J. N. Rhetorical strategies of consumer activists: reframing market offers to promote change. BAR - Brazilian Administration Review, v. 10, n. 4, p. 389-414, 2013.

SEIFERT, K. NFL dominates in U.S., but it lacks widespread appeal on international stage. ESPN, São Paulo, May 30, 2017. Available at: <http://www.espn.co.uk/nfl/story/_id/19472417/nfl-dominatesfan-audience-united-states-lacks-widespread-appeal-internationalstage >. Acessed on: Nov. 28, 2018.

SILVA, T. T. A produção social da identidade e da diferença. In: SILVA, T. T. (Ed.). Identidade e diferença. Petrópolis: Vozes, 2012.

THOMAS, T. C.; PRICE, L. L.; SCHAU, H. J. When differences unite: Resource dependence in heterogeneous consumption communities. Journal of Consumer Research, v. 39, n. 5, p. 1010-1033, 2013.

TILIO, R.C. Reflexões acerca do conceito de identidade. Revista Eletrônica do Instituto de Humanidades, v. 8, n. 29, p. 109-119, 2009.
VAN DIJCK, J. The Culture of Connectivity. A critical history of social media. New York: Oxford University Press, 2013.

WENNER, L. Reflections on Communication and Sport: On Reading Sport and Narrative Ethics. Communication \& Sport, v. 1, n. 1/2, p. 188-199, 2012.

WENNER, L. Connecting events to advertising: Narrative strategies and dirty logics in Super Bowl commercials In: DASHPER, K.; FLETCHER, T.; MCCULLOGH, N. (Eds). Sport Events, Society and Culture. Abingdon: Routledge, 2014.

WHANNEL, G. The paradoxical character of live television sport in the twenty-first century. Television \& New Media, v. 15, p. 769-776, 2014.

WOODWARD, K. Identidade e diferença: Uma introdução teórica e conceitual. In SILVA, T. T. (Ed.). Identidade e diferença: a perspectiva dos estudos culturais. Petrópolis: Vozes, 2012.

ZEUGNER-ROTH, K. P.; ZABKAR, V.; DIAMANTOPOULOS, A. Consumer Ethnocentrism, National Identity, and Consumer Cosmopolitanism as Drivers of Consumer Behavior: A Social Identity Theory Perspective. Journal of International Marketing, v. 23, n. 2, p. 25-54, 2015. 